•研究报告・

\title{
基于系统发育的黄土高原地区木本植物 多样性及特有性格局
}

\section{董雪苾 ${ }^{1}$ 张 红 ${ }^{2}$ 张明罡 ${ }^{*}$}

1 (山西大学黄土高原研究所, 太原 030006)

2 (山西大学环境与资源学院, 太原 030006)

\begin{abstract}
摘要: 黄土高原地区植被类型多样, 森林、草原和荒漠在此交汇并逐渐过渡。由于水热条件限制和人类活动加剧, 该地区生态环境脆弱, 生物多样性保护面临的形势日益严峻, 因此获取该区域物种多样性的空间分布格局并阐明 其影响因素成为该地区生物多样性保护的首要任务。本研究首先结合标本采集记录与环境因子, 利用物种分布模 型获取了293种木本植物的潜在分布区, 分析了物种丰富度和物种加权特有性的空间格局。其次, 引入系统发育信 息, 分析系统发育多样性和系统发育特有性的空间格局, 并进一步利用环境因子对上述格局分别进行解释。最后, 对黄土高原地区的特有中心性质和显著性进行分析。结果表明, 生物多样性热点地区均出现在黄土高原南部水热 条件较好的地区, 即秦岭和中条山一带。本区域的生物多样性空间格局由年平均降水量和最冷月最低温主导, 符 合植物区系交汇带的特点。特有中心集中在南部地区和青海省, 由南向北分别是古特有中心和混合特有中心, 不 存在单独的新特有中心。黄土高原地区木本植物起源较为古老, 生物多样性格局的形成以来源于热带或亚热带的 物种扩散为主, 物种的分化不占主导地位。上述结果表明了将植物的进化历史纳入生物多样性保护的重要性。
\end{abstract}

关键词: 多样性分布格局; 系统发育; 气候因子; 新特有; 古特有; 木本植物; 黄土高原地区

\section{Explaining the diversity and endemic patterns based on phylogenetic approach for woody plants of the Loess Plateau}

\author{
Xuerui Dong ${ }^{1}$, Hong Zhang ${ }^{2}$, Minggang Zhang ${ }^{1 *}$ \\ 1 Institute of Loess Plateau, Shanxi University, Taiyuan 030006 \\ 2 College of Environmental and Resource Sciences, Shanxi University, Taiyuan 030006
}

\begin{abstract}
The Loess Plateau is home to various vegetation types as it contains famous transitional forests, grasslands, and deserts. Due to natural resource limitation and intensive human activities, this natural environment faces serious conservation challenges. In order to effectively conserve this natural environment, spatial mapping of species diversity is key to conservation efforts. In this study, we first modeled the potential distribution of 293 woody species based on specimen records and climate data and then calculated the spatial patterns of species richness and weighted endemism. Secondly, we calculated phylogenetic diversity and phylogenetic endemism and identified environmental drivers of the observed spatial patterns. Finally, we analyzed endemism types and tested their significance. Our results suggest that biodiversity hotspots are distributed on the southern edge of the Loess Plateau and are highly related to the flora of Qinling Mountains. The biodiversity patterns of this transitional region are driven by annual precipitation and minimum temperature of coldest month. Endemism hotspots were found on the southern edge of the Loess Plateau, which contain paleo-endemism and mixed-endemism, but no neo-endemism. We concluded that most woody species of the Loess Plateau originated in tropical or subtropical regions, and the species richness patterns of this region are maintained by dispersal rather than speciation. Our study indicated the importance of incorporating the evolutionary history in biodiversity conservation.
\end{abstract}

收稿日期: 2019-07-10; 接受日期: 2019-12-12

基金项目: 国家自然科学基金(31700465)和山西省应用基础研究计划(201701D221217)

* 通讯作者 Author for correspondence. E-mail: zhangmg@sxu.edu.cn 
Key words: diversity distribution pattern; phylogeny; climatic factors; neo-endemism; paleo-endemism; woody plant; Loess Plateau

物种多样性的空间分布格局是生物多样性保 护的重要依据, 但是当前的研究大多停留在分类学 层面, 将物种视为独立、等价的个体(葛学军, 2015), 而没有考虑到物种之间存在错综复杂的亲缘关系, 忽略了物种在进化历史中积累的系统发育信息 (Qian et al, 2017)。将物种的系统发育信息纳入物种 多样性格局研究中, 可以更全面地了解进化历史过 程对于格局形成的影响, 从而更有效地保护生物多 样性, 保存生物进化潜能(Jetz et al, 2012; Barnabas et al, 2015; Shapcott et al, 2015)。

基于物种之间亲缘关系形成的物种谱系树也 称为系统发育树(陈之端和李德铢, 2013)。近30年来, 随着物种基因序列的积累以及建树方法的不断完 善, 系统发育学逐渐成为备受关注的热点学科 (Donoghue, 2008; 鲁丽敏等, 2014), 并由此衍生出 一系列的生物多样性测度指标。Faith (1992)提出以 支长为基础的系统发育多样性(phylogenetic diversity, PD), 该指标以系统发育树上符合最小距离路 径(minimum spanning path)的分支总和来表示, 不 受物种分类地位的影响, 有利于识别出累积了深远 进化历史的类群。有研究证明物种丰富度(species richness, SR)和系统发育多样性不一定存在正相关 性, 如Forest等(2007)在研究南非好望角东、西部植 物分布格局时发现物种丰富度和系统发育多样性 表现出了相反的趋势, 并认为具有较高系统发育多 样性的东部更具保护价值。也有研究提出, 系统发 育多样性并不一定能比物种水平的指标提供更多 信息, 但其代表了物种的进化历史, 或许反映了对 环境的适应能力(Barnabas et al, 2018)。

植物在进化历史过程中表现出不均衡的特性, 从而造成了植物的特有现象(黄继红等, 2013)。Crisp 等(2001)在研究植物特有现象的分布格局时提出加 权特有性(weighted endemism, WE), 该指数在物种 丰富度的基础上结合了物种的空间分布范围, 物种 的分布区越狭窄，被赋予的权重越高。随着系统发 育学的发展, Rosauer等(2009)提出系统发育特有性 (phylogenetic endemism, PE), 与加权特有性类似, 该指数在系统发育多样性的基础上考虑物种的分
布范围, 能识别出存在孤立物种的区域, 在系统进 化上这些物种通常携带有更多稀有的基因和性状。 为了进一步对特有中心的性质类型进行识别, Mishler等(2014)提出新、古特有中心分类(categorical analysis of neo- and paleo-endemism, CANAPE)方法，该方法基于相对系统发育特有性 (relative phylogenetic endemism, RPE)进行计算, 显 著高的相对系统发育特有性表示研究区域内存在 过多的长支, 这些类群可能曾经广泛存在, 但现在 分布范围较为狭窄, 这种情况被认为是古特有现象, 古特有现象明显的地区通常是物种的避难所。相反, 显著低的相对系统发育特有性意味着研究区域内 存在过多分布范围狭窄的短支, 它们可能因为分化 时间较短, 还未扩散到更大的区域, 这种情况称为 新特有现象, 新特有现象明显的地区物种分化速率 较快, 是物种的分化中心。已有学者对我国植物的 特有现象进行了深入研究, 如Huang等(2012)结合 中国特有物种空间分布以及系统发育信息, 分析了 我国特有木本种子植物分布格局及特有性热点地 区，但未进一步关注特有性中心的性质。

黄土高原地区自北而南跨越我国温带和暖温 带, 包括干旱、半干旱和半湿润地带(张厚华和黄占 斌，2001)，植被类型由荒漠和草原向森林过渡，西 北部为荒漠区, 北部为内蒙古草原植被区，南部跨 入暖温带落叶阔叶林, 是旱生、中生和水生植物交 汇和过渡的地带(王义风和肖向明, 1993)。该地区植 物种类丰富, 物种起源古老且原始类群丰富(张文 辉等, 2002)。但由于降水集中且多为暴雨, 黄土层 覆盖深厚且质地疏松, 该区水土流失严重, 生态环 境恶化, 造成物种濒危程度加剧, 遗传资源不断丧 失(王力等, 2004), 生物多样性保护形势严峻。长期 以来, 多名学者在该地区开展了相关研究: 唐志尧 等(2004)分析了太白山木本植物多样性的梯度格局, 并利用环境因子对其进行解释; 汤萃文等(2005)基 于甘肃省特有种子植物的多样性格局分析了该省 的优先保护区; 张殷波等(2014)研究了秦岭重点保 护植物的丰富度格局; 赵鸣飞等(2017)从进化的角 度分析了山西芦芽山草本植物多样性及其谱系结 
构的海拔格局。但是, 目前黄土高原地区仍然缺乏大 尺度的植物多样性格局及其形成机制的相关研究。

在大尺度的研究中, 气候通常被认为是影响物 种分布格局的关键因素 (Francis \& Currie, 2003; Wang et al, 2011; Qian, 2013)。本文以黄土高原地区 为研究区域, 结合气候因子与标本采集记录进行多 样性与特有性格局分析。由于该区尚未进行植物普 查, 大部分地区缺少物种记录, 标本记录远低于实 际丰富度，因而通过模拟得到物种的潜在分布区， 成为获取黄土高原地区木本植物生物多样性格局 地图的有效手段(Schmidt-Lebuhn et al, 2015)。进一 步结合进化历史分析了影响植物多样性格局的主 要气候因子, 并对黄土高原地区木本植物特有中心 的性质进行分类, 拟为该地区的生物多样性保护提 供科学依据。

\section{材料与方法}

\section{1 数据的获取与物种分布模型的构建}

黄土高原 $\left(100^{\circ} 54^{\prime}-114^{\circ} 33^{\prime} \mathrm{E}, 33^{\circ} 43^{\prime}-41^{\circ} 16^{\prime} \mathrm{N}\right)$ 位于我国中部，包括山西省和宁夏回族自治区全 境、陕西省中部和北部、甘肃省中部和东部、青海 省的东北部以及内蒙古自治区的河套平原和鄂尔 多斯高原等地区。本研究所使用的黄土高原边界数 据是在我国县级行政区划地图的基础上，依据Feng 等(2016)所使用的黄土高原边界范围在ArcGIS 10.2 中裁剪获得。为了与物种空间分布数据相匹配, 将 裁剪得到的图层重采样为 $10 \mathrm{~km} \times 10 \mathrm{~km}$ 的栅格, 黄 土高原地区共被划分为 9,112 个栅格。物种分布数据 来源于国家标本资源共享平台(National Specimen Information Infrastructure, NSII) (http://www. nsii.org. cn/2017/home.php/), 经初步篮选共获得 167,237条 标本数据。为确保数据的准确性与可用性, 首先通 过《中国植物志》在线版(http://frps.iplant.cn/)和 R 语言工具包(plantlist) (Zhang, 2017)对植物拉丁名进 行校正, 处理过程中仅保留野生种, 未考虑种下等 级(亚种、变种)。其次是将标本与经纬度匹配。由 于历史采集的大部分标本记录没有准确的经纬度 坐标, 因而根据标本标签上的采集信息将物种数据 归属到乡镇级或村级行政单位, 使用该乡镇级或村 级行政单位的经纬度作为该记录的坐标匹配到相 应的栅格中, 同一个物种在相同的栅格中仅保留唯 一采集记录, 代表该物种在本区域内存在。经过本
步骤共保留17,325条记录。最后，由于存在信息少 于 5 个栅格的物种在物种分布建模中没有统计学意 义(Wisz et al, 2008), 因此将10,125条分布记录共 153 个物种剔除。经过篮选整理, 最后保留的木本植 物标本记录有 7,200 条, 分为89科157属293种。

气候数据来源于世界气候数据库(http://www. worldclim.org/), 选择当前气候情境下(1970-2000年) 分辨率为 $10 \mathrm{~km} \times 10 \mathrm{~km}$ 的 19 个生物气候因子。为获 取每个物种的潜在分布区，本研究利用物种分布模 型的最大熵模型MaxEnt 3.3.3k (Phillips et al, 2006) (http://biodiversityinformatics.amnh.org/open_source/ maxent/)模拟分析物种的潜在分布区。由于建模过 程中预测因子之间的多重共线性问题会引起算法 的过度拟合(Graham, 2003), 所以对19个生物气候 因子进行了Spearman相关分析，相关性较小(相关 系数 < 0.75)且生态意义较大的因子被保留作为预 测因子(表1) (Zhang et al, 2017)。

最大熵模型建模算法规则设置如下: (1)物种采 集记录为5-9时采用线性算法，此时相当于广义线 性模型; (2)物种采集记录为10-15时采用二次方算 法; (3)物种采集记录> 15时采用复合算法(Raes \& Ter Steege, 2007)。由于经最大熵模型训练后获取的 图层为该物种在每个栅格中发生的概率值, 因此需 要设置一个阈值将概率值转换为逻辑值, 即该物种 存在或不存在。初始样本量的大小决定阈值的选取 规则：(1)对于采集记录为5-9的物种，采用特异性 和敏感性相等规则, 即模型预测的准确概率与遗漏 概率相等; (2)对于采集记录 $\geq 10$ 的物种，选取训练 后逻辑数列值的 $10 \%$, 认为该物种存在(Liu et al, 2018)。

上述设置均在MaxEnt模型中完成。模型精度依 据受试者工作特征曲线(ROC)与横坐标围成的面积, 即AUC值来评估, 本研究设定当AUC值 $\geq 0.75$ 时, 该模型精度满足要求(Marmion et al, 2009)。

\section{2 生物多样性指数的计算}

选取在线建树软件phylomatic (Webb \& Donoghue, 2005)为黄土高原地区293种木本植物构建系统 发育树, 选择Zanne等(2014)的进化树骨架, 分辨率 为属级分类水平，若进化树上没有该属的信息，则 到科级。该树基于APG III被子植物分类系统构建, 可以直接输出带有支长的进化树, 是至今为止最大 的植物系统发育树，在大尺度、多类群研究中被广 
表1 保留的环境因子间的Spearman相关系数

Table 1 Spearman correlation coefficient between reserved environmental variables

\begin{tabular}{|c|c|c|c|c|c|c|}
\hline & $\begin{array}{l}\text { 年平均温度 } \\
\text { Annual mean } \\
\text { temperature }\end{array}$ & $\begin{array}{l}\text { 平均日较差 } \\
\text { Mean diurnal } \\
\text { range }\end{array}$ & $\begin{array}{l}\text { 温度季节性 } \\
\text { Temperature } \\
\text { seasonality }\end{array}$ & $\begin{array}{l}\text { 最热月最高温 } \\
\text { Max. temperature of } \\
\text { warmest month }\end{array}$ & $\begin{array}{l}\text { 最冷月最低温 } \\
\text { Min. temperature } \\
\text { of coldest month }\end{array}$ & $\begin{array}{l}\text { 年平均降水量 } \\
\text { Annual } \\
\text { precipitation }\end{array}$ \\
\hline 平均日较差 Mean diurnal range & -0.197 & & & & & \\
\hline 温度季节性 Temperature seasonality & -0.110 & 0.750 & & & & \\
\hline $\begin{array}{l}\text { 最热月最高温 } \\
\text { Max. temperature of warmest month }\end{array}$ & 0.640 & 0.436 & 0.548 & & & \\
\hline $\begin{array}{l}\text { 最冷月最低温 } \\
\text { Min. temperature of coldest month }\end{array}$ & 0.727 & -0.713 & -0.687 & 0.059 & & \\
\hline 年平均降水量 Annual precipitation & 0.362 & -0.619 & -0.709 & -0.167 & 0.702 & \\
\hline 最干月降水量 Precipitation of driest month & 0.327 & -0.265 & -0.134 & 0.209 & 0.374 & 0.602 \\
\hline
\end{tabular}

泛应用(Qian \& Sandel, 2017)。本研究对如下 4 个指 数进行了计算:

(1)物种丰富度。它简单直观地反映了研究区域 的物种数量水平, 表示为所关注的空间单元内所有 物种的总和。

(2)物种加权特有性。根据物种的空间分布范围 设置每个物种的权重, 物种的分布区越小, 被赋予 的权重越高。具体计算公式为:

$$
W E=\sum_{i=1}^{n} W i
$$

其中, $n$ 是所关注的空间单元分布的物种数, $W i$ 是第 $i$ 个物种在该单元内的权重。

(3)系统发育多样性。定义为连接系统发育树上 所有物种的最短路径的分支长度总和, 具体计算公 式如下:

$$
P D=\sum_{\{c \in C\}} L c
$$

其中, $C$ 为研究区域内所有物种构成的系统发育树 最短路径支长总和, $c$ 为 $C$ 的一个分支, $L C$ 为 $c$ 的分 支长度。

(4)系统发育特有性。定义为研究区域内出现的 每个物种范围比例加权的长度总和, 公式如下:

$$
P E=\sum_{\{c \in C\}} L c / R c
$$

其中,是 $R c$ 为 $c$ 分支所代表物种的分布范围。

上述 4 个指数均在 Biodiverse 2.0 中进行计算 (Laffan et al, 2010), 与环境因子之间的关系在 SPSS 22.0 软件中通过逐步回归分析方法进行分析。

\section{3 特有中心类型分析与显著性检验}

系统发育多样性和系统发育特有性均是在实 际的系统发育树上计算所得, 引入零模型比较树 (即保留系统发育树的拓扑结构, 假设其分支长度
都相等)可以评估指数是高于期望值或低于期望值 (Mishler et al, 2014)。此时实际树与比较树系统发育 多样性的比率即为相对系统发育多样性 (relative phylogenetic diversity, RPD), 实际树与比较树系统 发育特有性的比率即为相对系统发育特有性。新、 古特有中心分类方法具体步骤如下：首先，识别实 际树或比较树系统发育特有性值显著高的网格(单 尾检验, $\alpha=0.05$ ) 并定义为特有中心; 其次, 根据这 些网格的相对系统发育特有性进行分类(双尾检验, $\alpha=0.05$ ), 显著高的为古特有中心, 显著低的为新 特有中心，不具显著性的为混合特有中心; 最后, 对混合特有中心进一步分类, 将实际树或比较树系 统发育特有性显著高的网格(单尾检验, $\alpha=0.01$ ) 定 义为超级混合特有中心。

PD、PE、RPD和RPE 4 个指数的统计学显著性 利用随机化零模型进行检验，具体方法是将出现的 物种重新随机分配给空间单元但不进行替换, 因此, 每个物种出现的单元数和每个单元的丰富度保持 不变。零模型运行999次进行随机化显著性检验(双 尾检验)。对于 4 个指数的显著性检验, 若显著性值> 0.975 , 则意味着该空间单元指数显著高于期望值; 若显著性值 $<0.025$, 则意味着该空间单元指数显著 小于期望值。上述分析均利用Biodiverse 2.0 完成 (Laffan et al, 2010)。

\section{结果}

将黄土高原地区木本植物潜在分布区地图相 叠加并进行系统发育分析, 获取了物种丰富度、物 种加权特有性、系统发育多样性以及系统发育特有 性4个指数的空间格局地图(图1)。总体而言，4个指 数均呈现出由东南向西北逐渐递减的趋势, 数值较 

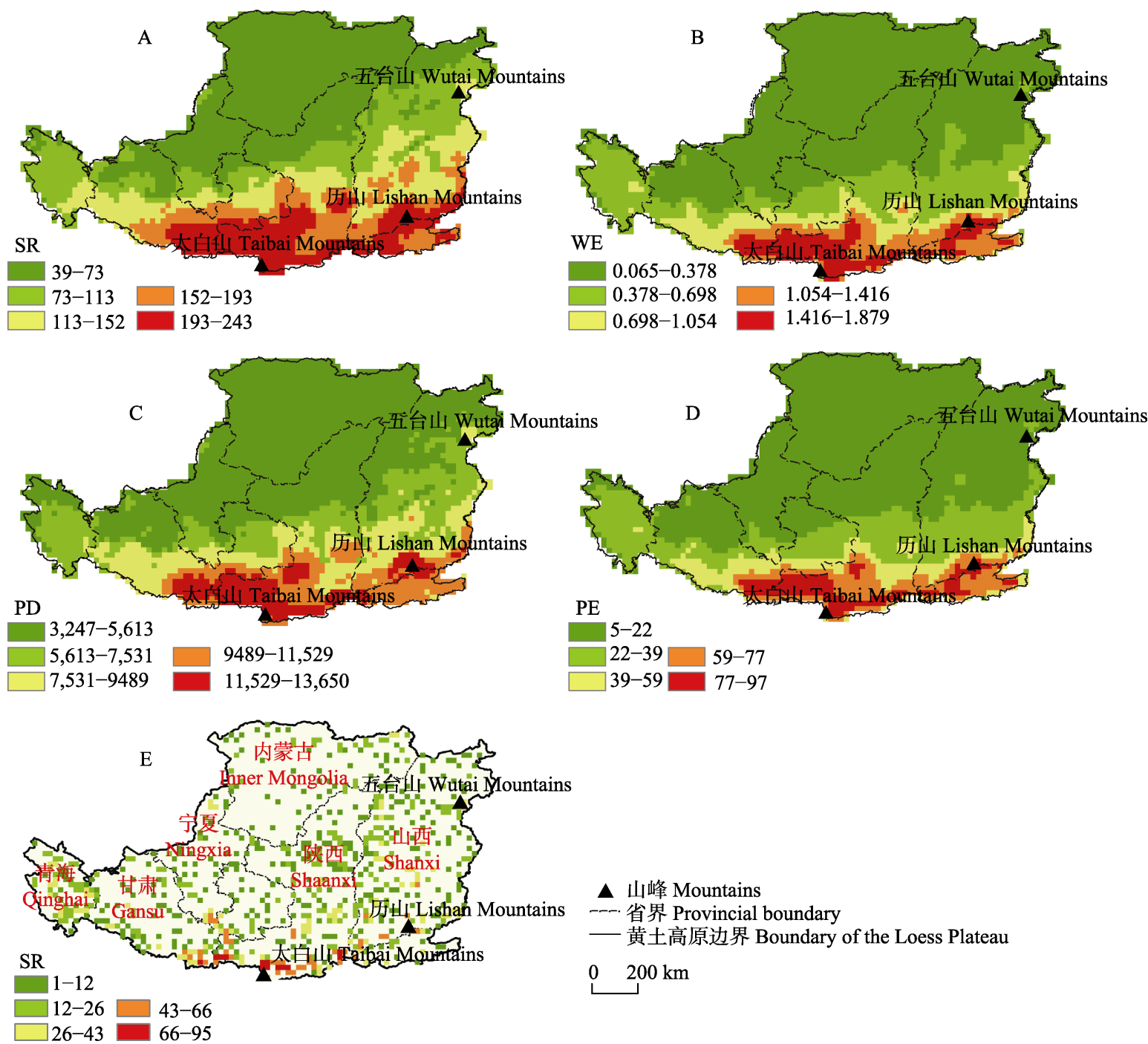

\山峰 Mountains 省界 Provincial boundary

一 黄土高原边界 Boundary of the Loess Plateau

$0 \quad 200 \mathrm{~km}$

图1 黄土高原地区木本植物多样性分布格局图。(A)物种丰富度(SR); (B)物种加权特有性(WE); (C)系统发育多样性(PD); (D) 系统发育特有性(PE); (E)采样记录物种丰富度。

Fig. 1 Spatial pattern of woody plant diversity in the Loess Plateau. (A) Species richness (SR); (B) Weighted endemism (WE); (C) Phylogenetic diversity (PD); (D) Phylogenetic endemism (PE); (E) Species richness of sampling records.

高的区域均出现在黄土高原南部狭长区域。采用自 然间断点分级法(Jenks' natural breaks)划分为 5 个等 级后可以看出, 生物多样性热点地区集中分布在黄 土高原南部的秦岭(太白山)、中条山和历山一带。

逐步回归分析表明, 年平均降水量和最冷月最 低温两个因子对于物种丰富度、物种加权特有性和 系统发育多样性的解释能力分别达到 $77.2 \%$ 、65.8\% 和 $76.6 \%$ 。最冷月最低温单因子对于系统发育特有 性的解释能力达到 $52 \%$ (表2)。

随机显著性检验表明(图2), 对于PD、PE、RPD 和RPE，黄土高原中部的观测值显著低于期望值。 对于PE和RPE, 黄土高原南部地区的观测值显著高
于期望值。黄土高原地区木本植物的特有现象集中 在南部地区和青海省，由南向北分别出现了古特有 中心和混合特有中心，不存在单独的新特有中心， 呈现出较为明显的扩散趋势。青海省具有显著的混 合特有现象(图3)。

\section{3 讨论}

黄土高原地区木本植物的物种丰富度、物种加 权特有性、系统发育多样性和系统发育特有性表现 出了相似的趋势，即生物多样性热点地区均集中在 该地区南部狭长地带, 与秦岭植物区关系密切(张 殷波等，2014)。其中，黄土高原南部的太白山和中 
表2 黄土高原地区气候因子与生物多样性指数多元逐步回归的结果。 $R_{\mathrm{adj}}^{2}$ : 标准化决定系数; Beta: 回归系数; $t$ : 回归系数 $t$ 检验。

Table 2 Results of multiple stepwise regression of climatic factors and biodiversity indices in the Loess Plateau. $R_{\mathrm{adj}}^{2}$ : the adjusted coefficients of determination; Beta: the standardized regression coefficient; $t$ : $t$ test for the regression coefficient.

\begin{tabular}{|c|c|c|c|}
\hline & $R_{\text {adj. }}^{2}$ & Beta & $t$ \\
\hline \multicolumn{4}{|l|}{ 物种丰富度 Species richness } \\
\hline 年平均降水量 Annual precipitation & 0.656 & 0.438 & 31.316 \\
\hline 最冷月最低温 Min. temperature of coldest month & 0.772 & 0.392 & 30.247 \\
\hline 最干月降水量 Precipitation of driest month & 0.777 & 0.098 & 8.549 \\
\hline 平均日较差 Mean diurnal range & 0.782 & -0.097 & 7.798 \\
\hline \multicolumn{4}{|l|}{ 物种加权特有性 Weighted endemism } \\
\hline 年平均降水量 Annual precipitation & 0.544 & 0.197 & 9.037 \\
\hline 最冷月最低温 Min. temperature of coldest month & 0.658 & -0.445 & -2.245 \\
\hline 最干月降水量 Precipitation of driest month & 0.682 & 0.288 & 16.948 \\
\hline 最热月最高温 Max. temperature of warmest month & 0.700 & 0.661 & 3.831 \\
\hline 平均日较差 Mean diurnal range & 0.701 & -0.359 & -5.554 \\
\hline 温度季节性 Temperature seasonality & 0.704 & -0.847 & -4.621 \\
\hline \multicolumn{4}{|l|}{ 系统发育多样性 Phylogenetic diversity } \\
\hline 年平均降水量 Annual precipitation & 0.652 & 0.411 & 21.770 \\
\hline 最冷月最低温 Min. temperature of coldest month & 0.766 & -1.014 & -5.746 \\
\hline 平均日较差 Mean diurnal range & 0.771 & -0.466 & -8.296 \\
\hline 最干月降水量 Precipitation of driest month & 0.775 & 0.121 & 8.308 \\
\hline 温度季节性 Temperature seasonality & 0.777 & -1.215 & -7.670 \\
\hline 最热月最高温 Max. temperature of warmest month & 0.781 & 0.885 & 4.931 \\
\hline 年平均温度 Annual mean temperature & 0.782 & 0.264 & 2.219 \\
\hline \multicolumn{4}{|l|}{ 系统发育特有性 Phylogenetic endemism } \\
\hline 最冷月最低温 Min. temperature of coldest month & 0.520 & -0.443 & -2.166 \\
\hline 年平均降水量 Annual precipitation & 0.633 & 0.157 & 6.957 \\
\hline 最干月降水量 Precipitation of driest month & 0.659 & 0.307 & 17.472 \\
\hline 最热月最高温 Max. temperature of warmest month & 0.680 & 0.653 & 3.666 \\
\hline 平均日较差 Mean diurnal range & 0.681 & -0.352 & -5.270 \\
\hline 温度季节性 Temperature seasonality & 0.683 & -0.866 & -4.572 \\
\hline
\end{tabular}

条山地区具有较高的代表性。太白山是秦岭植物区 的一部分, 地处中国亚热带和暖温带的过渡带上, 物种丰富, 组成复杂, 是中国生物样性最丰富的地 区之一(唐志尧等, 2004)。中条山位于山西省南部, 东邻太行山, 西与秦岭相望, 植物区系丰富, 其中 有大量珍稀濒危植物(上官铁梁等, 2000)。从区域尺 度来看, 黄土高原南部的物种多呈狭域分布, 因此 特有性权重较高。

黄土高原地区是我国半干旱区到半湿润区的 过渡地带, 降水分布极不均匀, 多集中在6-9月(王 毅荣等, 2004)。水分对于植被的生产力有着最直接 的影响, 在本研究中, 物种丰富度、物种加权特有 性和系统发育多样性 3 个指数与年平均降水量均呈 显著的正相关关系, 说明水分是黄土高原半干旱地 区植物生长与植被恢复的主要限制因子。Shi等
(2016)通过对黄土高原地区的草本植物年轮解剖发 现: 黄土高原地区的植物生长对干旱胁迫有较为敏 感的响应, 这意味着水分条件是决定黄土高原植物 生长的先决条件; 另外, 气候变暖导致的干旱胁迫 会对黄土高原植物生长产生明显的负面影响。本研 究中, 物种丰富度、物种加权特有性和系统发育多 样性 3 个指数与最冷月最低温呈负相关关系, 说明 低温限制是影响物种丰富度的另一重要因素, 黄土 高原地区南部的物种多具有热带属性, 生态位的保 守性限制了这些物种的向北扩散(Xu et al, 2013; Kerkhoff et al, 2014)。Wang等(2011)利用气候因子、 生境异质性和人类活动等指标构建了中国木本植 物的解释模型, 发现最冷季的平均温度对木本植物 丰富度解释能力最高 $(60 \%-73 \%)$, 支持 “低温限制” 假说，尤其是对于有热带亲缘的类群而言。 

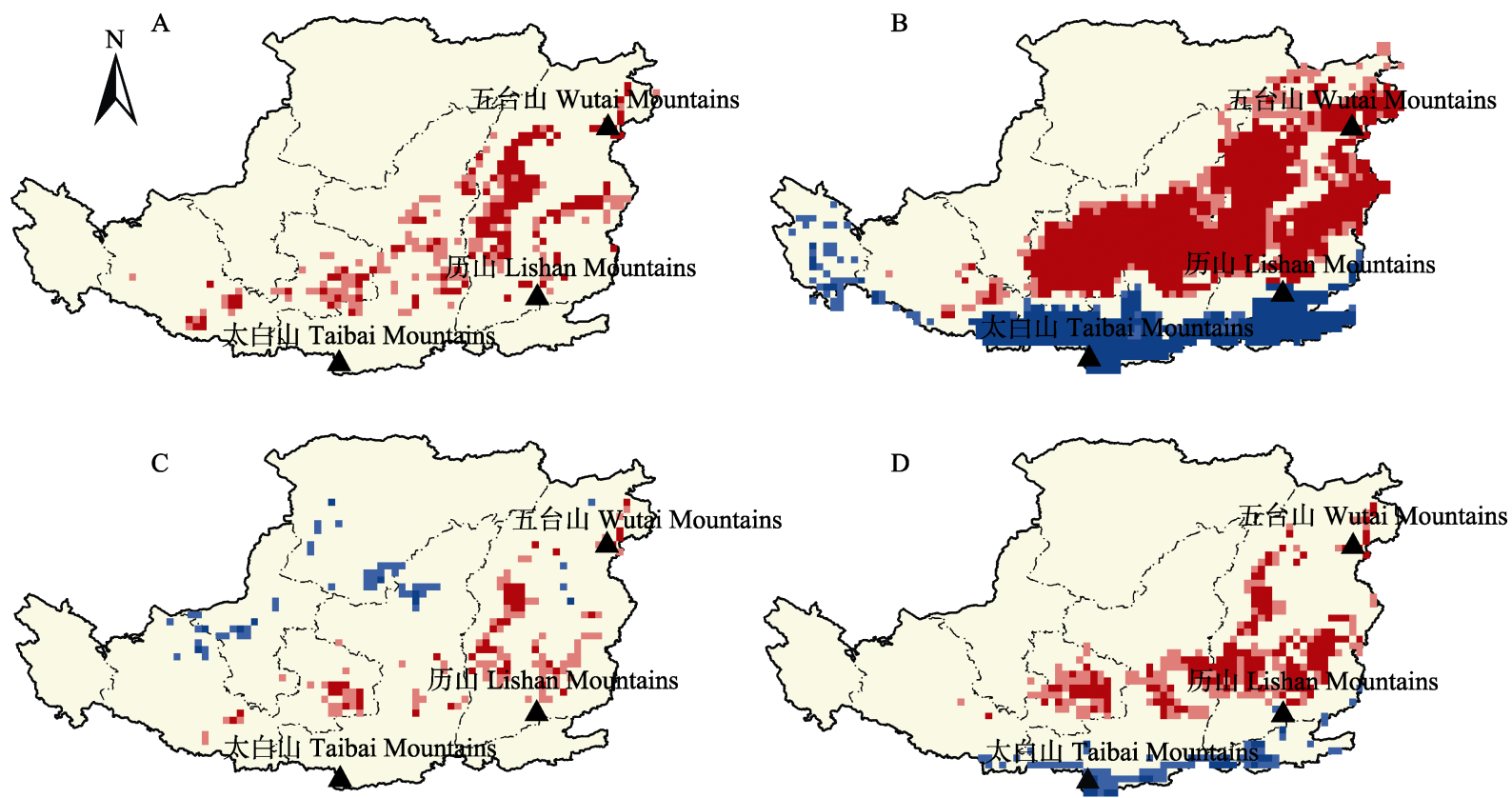

A 山峰 Mountains

- - 省界 Provincial boundary

一 黄土高原边界 Boundary of the Loess Plateau

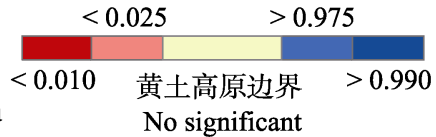

$0 \quad 200 \mathrm{~km}$

图2 黄土高原地区木本植物多样性指数的显著性检验结果图。(A)系统发育多样性; (B)系统发育特有性; (C)相对系统发育多 样性; (D)相对系统发育特有性。

Fig. 2 Spatial pattern of significant metrics of woody plant in the Loess Plateau. (A) Phylogenetic diversity; (B) Phylogenetic endemism; (C) Relative phylogenetic diversity; (D) Relative phylogenetic endemism.

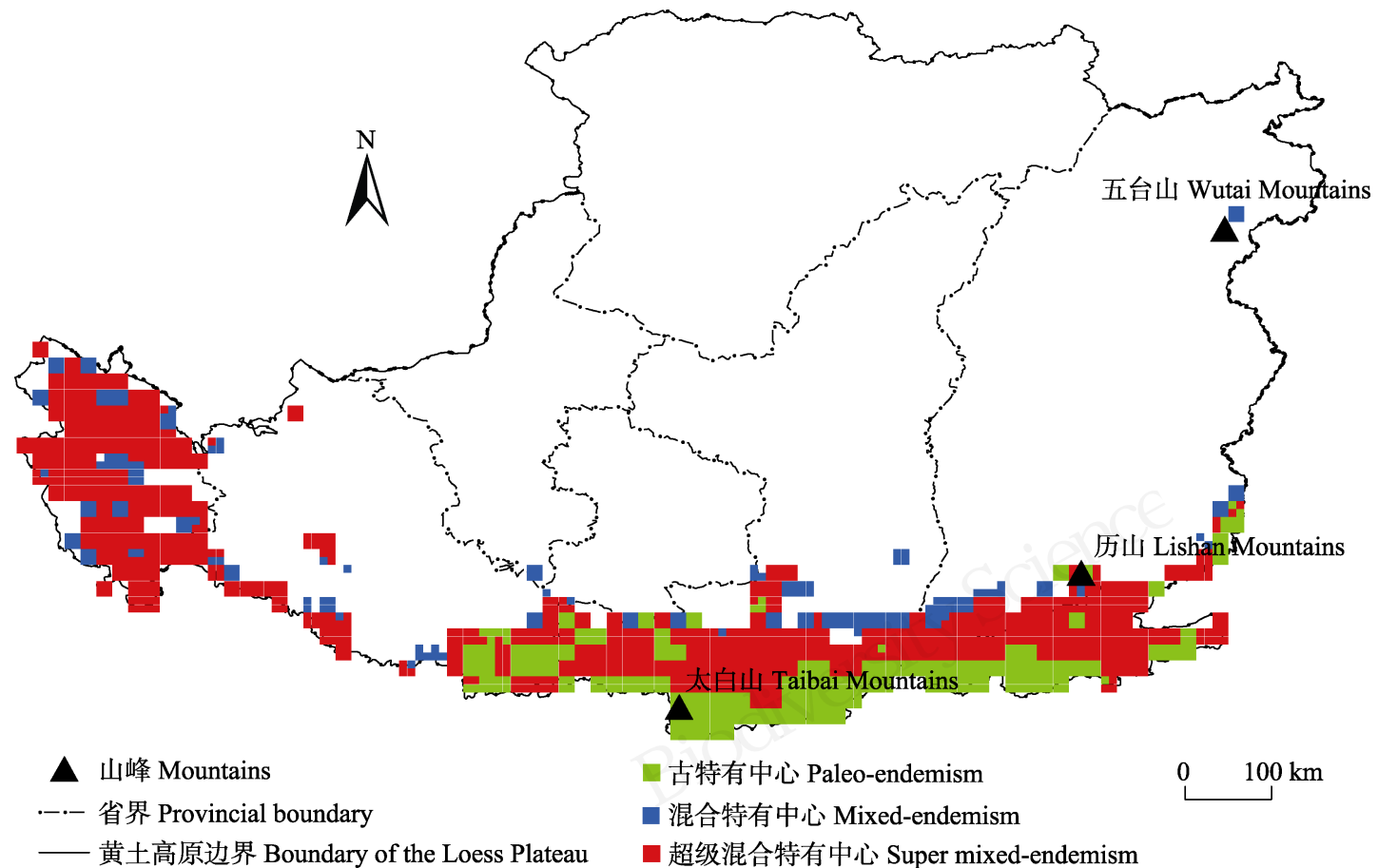

图3 黄土高原地区木本植物新、古特有中心分类

Fig. 3 The categorical analysis of neo- and paleo-endemism of woody plants in the Loess Plateau 
在随机零模型检验中, 系统发育多样性、系统 发育特有性、相对系统发育多样性和相对系统发育 特有性 4 个指数在黄土高原中部地区(山西省与陕西 省中部)显著低于观测值, 说明该区域内的物种起 源较为古老, 在迁移的过程中受到秦岭及中条山脉 的横向阻隔而未能向北扩散。对于系统发育特有性 和相对系统发育特有性两个指数, 随机零模型检验 表明在黄土高原地区南部其期望值显著高于观测值, 说明该区域内存在较多的年轻分支，尚未向北扩散。 根据木本植物的多样性分布格局及特有中心性质 分类的结果, 黄土高原地区植物区系过渡性特点十 分明显，具有热带亲缘的物种在该区域内占较高的 比重。青海省具有超级混合特有现象, 推测是因该地 区山脉较多造成地理隔离，限制了植物的扩散迁移。

本研究的生物多样性格局是基于物种潜在分 布区地图获得，当前黄土高原地区尚未进行植物普 查或标本的系统采集，因此通过原始资料收集的记 录远低于现实丰富度, 而且大部分空间单元中物种 记录为缺失, 仅有 $7 \%$ 的空间单元存在物种记录(图 $1 \mathrm{~A} 、 1 \mathrm{E})$, 而物种分布模型能够对此类物种存在信息 的缺失做出较好的补充。但是以模拟的方式获取的 丰富度地图仍然存在较大的不确定性：(1)物种分布 模型所获取的是物种的气候适生区，但是现实中物 种分布受扩散能力、种间相互作用等因素制约, 潜 在分布区与实际分布区可能存在较大的差异(Merow et al, 2013); (2)虽然本文中使用的黄土高原地区 是地理边界, 但是该地区内尚未进行过标本的系统 采集，标本的采集完整程度存在较大的不确定性; (3)由于部分物种样本量过少, 在物种分布建模中不 具统计学意义, 本研究对该部分物种进行了剔除, 但这类物种仍可能为狭域种或极小种群，对生物多 样性保护有着较高的现实意义(Ma et al, 2013)。将 来, 随着物种分布建模理论的不断发展以及标本采 集量的逐渐丰富, 模拟结果的可靠性能够在很大程 度上得到提高。

\section{参考文献}

Barnabas HD, Michelle B, Davies TJ (2015) Spatial incongruence among hotspots and complementary areas of tree diversity in southern Africa. Diversity and Distributions, 21, 769-780.

Barnabas HD, Peter LR, Jeyanthi G, Daniel SP, Ben GH, Michelle G (2018) Spatial overlaps between the global protected areas network and terrestrial hotspots of evolutionary diversity. Global Ecology and Biogeography, 28, 757-766.

Chen ZD, Li DZ (2013) On Barcode of Life and Tree of Life. Plant Diversity and Resources, 35, 675-681. (in Chinese with English abstract) [陈之端, 李德铢 (2013) 生命条形 码与生命之树. 植物分类与资源学报, 35, 675-681.]

Crisp MD, Laffan SW, Linder HP, Monro A (2001) Endemism in the Australian flora. Journal of Biogeography, 28, 183-198.

Donoghue MJ (2008) A phylogenetic perspective on the distribution of plant diversity. Proceedings of the National Academy of Sciences, USA, 105, 11549-11555.

Faith DP (1992) Conservation evaluation and phylogenetic diversity. Biological Conservation, 61, 1-10.

Feng XM, Fu BJ, Piao SL, Wang S, Ciais P, Zeng ZZ, Lu Y, Zeng Y, Li Y, Jiang XH, Wu BF (2016) Revegetation in China's Loess Plateau is approaching sustainable water resource limits. Nature Climate Change, 6, 1019-1022.

Forest F, Grenyer R, Rouget M, Davies TJ, Cowling RM, Faith DP, Balmford A, Manning JC, Proches S, van der Bank M, Reeves G, Hedderson TAJ, Savolainen V (2007) Preserving the evolutionary potential of floras in biodiversity hotspots. Nature, 445, 757-760.

Francis AP, Currie DJ (2003) A globally consistent richnessclimate relationship for angiosperms. The American Naturalist, 161, 523-536.

Ge XJ (2015) Application of DNA barcoding in phylofloristics study. Biodiversity Science, 23, 295-296. (in Chinese) [葛 学军 (2015) DNA条形码在植物系统发育区系学研究中 的应用. 生物多样性, 23, 295-296.]

Graham MH (2003) Confronting multicollinearity in ecological multiple regression. Ecology, 84, 2809-2815.

Huang JH, Chen B, Liu CR, Lai JS, Zhang JL, Ma KP (2012) Identifying hotspots of endemic woody seed plant diversity in China. Diversity and Distributions, 18, 673-688.

Huang JH, Zhang JL, Yang Y, Ma KP (2013) Advances in methods for measuring patterns of endemic plant diversity. Biodiversity Science, 21, 99-110. (in Chinese with English abstract) [黄继红，张金龙，杨永，马克平 (2013) 特有植 物多样性分布格局测度方法的新进展. 生物多样性, 21, 99-110.]

Jetz W, Thomas GH, Joy JB, Hartmann K, Mooers AO (2012) The global diversity of birds in space and time. Nature, 491, 444-448.

Kerkhoff AJ, Moriarty PE, Weiser MD (2014) The latitudinal species richness gradient in New World woody angiosperms is consistent with the tropical conservatism hypothesis. Proceedings of the National Academy of Sciences, USA, 111, 8125-8130.

Laffan SW, Lubarsky E, Rosauer DF (2010) Biodiverse, a tool for the spatial analysis of biological and related diversity. Ecography, 33, 643-647.

Liu CR, White M, Newell G (2018) Detecting outliers in 
species distribution data. Journal of Biogeography, 45, 164-176.

Lu LM, Sun M, Zhang JB, Li HL, Lin L, Yang T, Chen M, Chen ZD (2014) Tree of life and its applications. Biodiversity Science, 22, 3-20. (in Chinese with English abstract) [鲁丽敏, 孙苗, 张景博, 李宏雷, 林立, 杨拓, 陈闽, 陈 之端 (2014) 生命之树及其应用. 生物多样性, 22, 3-20.]

Ma YP, Chen G, Grumbine ED, Dao ZL, Sun WB, Guo HJ (2013) Conserving plant species with extremely small populations (PSESP) in China. Biodiversity and Conservation, 22, 803-809.

Marmion M, Parviainen M, Luoto M, Heikkinen RK, Thuiller W (2009) Evaluation of consensus methods in predictive species distribution modelling. Diversity and Distributions, 15, 59-69.

Merow C, Smith MJ, Silander JA (2013) A practical guide to MaxEnt for modeling species' distributions: What it does, and why inputs and settings matter. Ecography, 36, 1058-1069.

Mishler BD, Knerr N, Gonzalez-Orozco CE, Thornhill AH, Laffan SW, Miller JT (2014) Phylogenetic measures of biodiversity and neo- and paleo-endemism in Australian Acacia. Nature Communications, 5, 4473.

Phillips SJ, Anderson RP, Schapire RE (2006) Maximum entropy modeling of species geographic distributions. Ecological Modelling, 190, 231-259.

Qian H (2013) Environmental determinants of woody plant diversity at a regional scale in China. PLoS ONE, 8, e75832.

Qian H, Jin Y, Ricklefs RE (2017) Phylogenetic diversity anomaly in angiosperms between eastern Asia and eastern North America. Proceedings of the National Academy of Sciences, USA, 114, 11452-11457.

Qian H, Sandel B (2017) Phylogenetic structure of regional angiosperm assemblages across latitudinal and climatic gradients in North America. Global Ecology and Biogeography, 26, 1258-1269.

Raes N, Ter Steege H (2007) A null-model for significance testing of presence-only species distribution models. Ecography, 30, 727-736.

Rosauer D, Laffan SW, Crisp MD, Donnellan SC, Cook LG (2009) Phylogenetic endemism: A new approach for identifying geographical concentrations of evolutionary history. Molecular Ecology, 18, 4061-4072.

Schmidt-Lebuhn AN, Knerr NJ, Miller JT, Mishler BD (2015) Phylogenetic diversity and endemism of Australian daisies (Asteraceae). Journal of Biogeography, 42, 1114-1122.

Shangguan TL, Zhang F, Fan LS (2000) Analysis on the flora of xylophyta in Zhongtiao Mountains, Shanxi. Bulletin of Botanical Research, 20, 143-155. (in Chinese with English abstract) [上官铁梁, 张峰, 樊龙锁 (2000) 中条山木本植 物区系地理成分分析. 植物研究, 20, 143-155.]

Shapcott A, Forster PI, Guymer GP, McDonald WJF, Faith DP, Erickson D, Kress WJ (2015) Mapping biodiversity and setting conservation priorities for SE Queensland's rainforests using DNA barcoding. PLoS ONE, 10, e0122164.

Shi SL, Li ZS, Wang H, Arx GV, Lü YH, Wu X, Wang XC, Liu GH, Fu BJ (2016) Roots of forbs sense climate fluctuations in the semi-arid Loess Plateau: Herb-chronology based analysis. Scientific Reports, 6, 28535.

Tang CW, Sun XG, Xiao DN (2005) Priority area assessment for species diversity conservation of spermatophytic genera endemic to China in Gansu Province. Chinese Journal of Ecology, 24, 1127-1133. (in Chinese with English abstract) [汤萃文, 孙学刚, 肖笃宁 (2005) 甘肃省中国种子植物 特有属物种多样性保护优先地区分析. 生态学杂志, 24, 1127-1133.]

Tang ZY, Fang JY, Zhang L (2004) Patterns of woody plant species diversity along environmental gradients on Mt. Taibai, Qinling Mountains. Biodiversity Science, 12, 115-122. (in Chinese with English abstract) [唐志尧, 方精云, 张玲 (2004) 秦岭太白山木本植物物种多样性的梯度格局及环 境解释. 生物多样性, 12, 115-122.]

Wang L, Li YY, Li YY (2004) The eco-environment deterioration and its counter measures in the Loess Plateau. Journal of Natural Resources, 19, 263-271. (in Chinese with English abstract) [王力, 李裕元, 李种种 (2004) 黄土高 原生态环境的恶化及其对策. 自然资源学报, 19, 263-271.]

Wang YF, Xiao XM (1993) Climatic gradient of main vegetation types in the Loess Plateau region. Acta Botanica Sinica, 35, 291-299. (in Chinese with English abstract) [王义 凤, 肖向明 (1993) 黄土高原地区主要植被类型的气候 梯度分布. 植物学报, 35, 291-299.]

Wang YR, Yin XZ, Yuan ZP (2004) Main characteristics of climate system in Loess Plateau in China. Journal of Catastrophology, 19(S1), 39-45. (in Chinese with English abstract) [王毅荣, 尹宪志, 袁志鹏 (2004) 中国黄土高原 气候系统主要特征. 灾害学, 19(S1), 39-45.]

Wang ZH, Fang JY, Tang ZY, Lin X (2011) Patterns, determinants and models of woody plant diversity in China. Proceedings of the Royal Society B: Biological Sciences, 278, 2122-2132.

Webb CO, Donoghue MJ (2005) Phylomatic: Tree assembly for applied phylogenetics. Molecular Ecology Notes, 5, 181-183.

Wisz MS, Hijmans RJ, Li J, Peterson AT, Graham CH, Guisan A (2008) Effects of sample size on the performance of species distribution models. Diversity and Distributions, 14, 763-773.

Xu XT, Wang ZH, Rahbek C, Lessard JP, Fang JY (2013) Evolutionary history influences the effects of water-energy dynamics on oak diversity in Asia. Journal of Biogeography, 40, 2146-2155.

Zanne AE, Tank DC, Cornwell WK, Eastman JM, Smith SA, FitzJohn RG, McGlinn DJ, O’Meara BC, Moles AT, Reich PB, Royer DL, Soltis DE, Stevens PF, Westoby M, Wright 
IJ, Aarssen L, Bertin RL, Calaminus A, Govaerts R, Hemmings F, Leishman MR, Oleksyn J, Soltis PS, Swenson NG, Warman L, Beaulieu JM (2014) Three keys to the radiation of angiosperms into freezing environments. Nature, 506, 89-92.

Zhang HH, Huang ZB (2001) Bio-climatic division and restoration of the degraded ecosystem on the Loess Plateau. Journal of Arid Land Resources and Environment, 15(1), 64-71. (in Chinese with English abstract) [张厚华, 黄占斌 (2001) 黄土高原生物气候分区与该区生态系统的恢复. 干旱区 资源与环境, 15(1), 64-71.]

Zhang JL (2017) plantlist: Looking up the Status of Plant Scientific Names based on the Plant List Database. $\mathrm{R}$ package version 0.3.0. https://github.com/helixcn/plantlist/. (accessed on 2019-01-06)

Zhang MG, Slik JWF, Ma KP (2017) Priority areas for the conservation of perennial plants in China. Biological Conservation, 210, 56-63.

Zhang WH, Li DW, Liu GB, Xu XH (2002) The characteristics of the seed plant flora in Loess Plateau. Bulletin of Botanical Research, 22, 373-379. (in Chinese with English abstract) [张文辉, 李登武, 刘国涁, 徐学华 (2002) 黄土 高原地区种子植物区系特征. 植物研究, 22, 373-379.]

Zhang YB, Guo LL, Wang W, Tian Y, Li JS (2014) Spatial distribution patterns of species richness and hotspots of protected plants in Qinling Mountain. Acta Ecologica Sinica, 34, 2109-2117. (in Chinese with English abstract) [张殷波, 郭柳琳, 王伟, 田瑜, 李俊生 (2014) 秦岭重点 保护植物丰富度空间格局与热点地区. 生态学报, 34, 2109-2117.]

Zhao MF, Xue F, Wang YH, Wang GY, Xing KX, Kang MY, Wang JL (2017) Phylogenetic structure and diversity of herbaceous communities in the conifer forests along an elevational gradient in Luya Mountain, Shanxi, China. Chinese Journal of Plant Ecology, 41, 707-715. (in Chinese with English abstract) [赵鸣飞, 薛峰, 王宇航, 王国义, 邢 开雄, 康慕谊, 王菁兰 (2017) 山西芦芽山针叶林草本层 群落谱系结构与多样性的海拔格局. 植物生态学报, 41 , 707-715.] 